\title{
UPAYA MENINGKATKAN HASIL BELAJAR SISWA KELAS V MATA PELAJARAN IPA MATERI EKOSISTEM DENGAN MENGGUNAKAN MODEL PEMBELAJARAN DISCOVERY LEARNING
}

\author{
Dwi Purnomo, Zuchrotus Salamah \\ Universitas Ahmad Dahlan \\ wildfiredwi@gmail.com \\ szuchrotus@yahoo.com
}

\begin{abstract}
This research is based on the problem of the low student learning outcomes in science learning at Muhammadiyah Elementary School Klepu, Sleman Regency. The teacher still uses a conventional learning model so that the learning atmosphere becomes rigid and ultimately makes student learning outcomes lower. Therefore the teacher seeks to use the Discovery Learning learning model to create an interesting and enjoyable learning atmosphere. This study aims to improve learning outcomes of science through the Discovery Learning learning model in fifth grade students of SD Muhammadiyah Klepu Sleman Regency Academic Year 2018/2019. This type of research is classroom action research. This research was conducted in 2 cycles. This research was conducted on fifth grade students of SD Muhammadiyah Klepu Sleman Regency. Data was collected using observation sheets and test questions. The data analysis technique in this study is descriptive analysis. The results of this study indicate that learning through the Discovery Learning learning model can improve student science learning outcomes. The average value of post-test Cycle I is 62.2 and the percentage of mastery learning is $9.5 \%$. In the second cycle the average score of the post-test increased to 80.91 and the percentage of mastery learning was $76.2 \%$. Based on data obtained from the study, it can be concluded that learning through the Discovery Learning learning model can improve student learning outcomes.
\end{abstract}

Keywords: Model, Discovery Learning, Learning Outcomes, Science.

\begin{abstract}
ABSTRAK
Penelitian ini dilatabelakangi oleh permasalahan rendahnya hasil belajar siswa pada pembelajaran IPA di SD Muhammadiyah Klepu Kabupaten Sleman. Guru masih menggunakan model pembelajaran yang konvensional sehingga membuat suasana belajar menjadi kaku dan akhirnya membuat hasil belajar siswa menjadi rendah. Oleh karena itu guru berupaya menggunakan model pembelajaran Discovery Learning agar tercipta suasana pembelajaran yang menarik dan menyenangkan. Penelitian ini bertujuan untuk meningkatkan hasil belajar IPA melalui model pembelajaran Discovery Learning pada siswa kelas V SD Muhammadiyah Klepu Kabupaten Sleman Tahun Pelajaran 2018/2019. Jenis penelitian ini adalah penelitian tindakan kelas. Penelitian ini dilaksanakan dalam 2 siklus. Penelitian ini dilaksanakan pada siswa kelas V SD Muhammadiyah Klepu Kabupaten Sleman. Data dikumpulkan menggunakan lembar observasi dan soal tes. Teknik analisis data dalam penelitian ini adalah analisis deskriptif. Hasil penelitian ini menunjukkan bahwa
\end{abstract}


pembelajaran melalui model pembelajaran Discovery Learning dapat meningkatkan hasil belajar IPA siswa. Nilai rata - rata post-test Siklus I adalah 62,2 dan persentase ketuntasan belajarnya adalah $9,5 \%$. Pada siklus II nilai rata - rata post-testnya meningkat menjadi 80,91 dan persentase ketuntasan belajarnya adalah $76,2 \%$, Berdasarkan data yang diperoleh dari penelitian, dapat disimpulkan bahwa pembelajaran melalui model pembelajaran Discovery Learning dapat meningkatkan hasil belajar siswa.

Kata Kunci: Model, Discovery Learning, Hasil Belajar, IPA

\section{PENDAHULUAN}

Peningkatan kualitas pembelajaran terus dilakukan oleh seluruh komponen pendidikan dan pembelajaran di sekolah. Komponen pendidikan yang sangat berpotensi untuk meningkatkan kualitas pembelajaran di sekolah adalah guru. Berbagai upaya dilakukan guru untuk meningkatkan kualitas pembelajarannya, diantaranya dengan menerapkan model pembelajaran inovatif.

Salah satu mata pelajaran yang menuntut kreativitas guru dan siswa dalam pembelajarannya agar mudah dipahami yaitu Ilmu Pengetahuan Alam (IPA). Kelemahan pembelajaran IPA di sekolah dasar pada umumnya yaitu penggunaan model pengajaran yang kurang variatif. Penggunaan model pengajaran yang kurang tepat akan mengakibatkan rendahnya hasil belajar siswa. Guru biasanya menerapkan proses pembelajaran yang konvensional dimana hanya guru berceramah dalam proses belajar mengajarnya. Di sini siswa kurang aktif belajar karena hanya mendengarkan ceramah, mencatat tulisan di papan tulis, serta mengajarkan tugas. Suasana kelas yang terlihat sangat kaku dan menjenuhkan menyebabkan anak kurang mampu memahami materi yang disampaikan oleh guru.

Berdasarkan hasil wawancara dengan guru kelas V SD Muhammadiyah Klepu Kabupaten Sleman menunjukkan bahwa hasil belajar mata pelajaran IPA pada materi ekosistem relatif rendah. Lebih dari 50\% siswa belum mencapai kriteria ketuntasan minimal (KKM) yang telah ditetapkan yaitu 75. Berdasarkan hasil observasi, guru lebih sering menggunakan model pembelajaran yang konvensional, yang tidak memacu keaktifan siswa. Guru hanya memberikan ceramah di depan kelas yang kadang diselingi sedikit tanya jawab dengan siswa. Kemudian siswa disuruh mencatat apa yang tertulis di papan tulis dan mengerjakan tugas. Suasana kelas yang kaku membuat siswa kurang termotivasi untuk belajar. Siswa masih jarang diajak berdiskusi bersama mengenai apa yang sedang dipelajari. Saat proses pembelajaran siswa masih sering tidak memperhatikan guru mengajar. Siswa juga masih belum berani berpendapat dan bertanya apa bila ada yang belum diahami, serta tidak mau ikut serta dalam mengerjakan tugas. Hayat dan Yusuf (Wisudawati dan Sulistyowati, 2014: 11) menyatakan bahwa hasil belajar IPA yang dicapai oleh peserta didik di Indonesia yang tergolong rendah dipengaruhi oleh banyak faktor, yaitu karakteristik peserta didik dan keluarga, kemampuan membaca, motivasi belajar, minat dan konsep diri, strategi belajar, tingkat kehadiran, dan rasa memiliki.

Pembelajaran pada Kurikulum 2013 menuntut siswa untuk aktif, dan guru berperan sebagai fasilitator, sehingga dalam proses pembelajaran siswa berperan menjadi subjek, bukan objek pembelajaran yang hanya menerima apa yang di sampaikan oleh guru Oleh karena itu, guru diberikan kebebasan dalam menggunakan model pembelajaran yang menarik sehingga akan membuat siswa termotivasi untuk belajar, dan akhirnya mencapai hasil belajar yang baik.

Upaya guru sekolah dasar untuk meningkatkan hasil belajar siswa dapat dilakukan dengan berbagai cara, diantaranya dengan menggunakan model pembelajaran yang variatif. 
Dari beberapa model pembelajaran, salahsatu model pembelajaran yang diasumsikan dapat meningkatkan hasil belajar siswa adalah model pembelajaran Discovery Learning, dimana dalam model tersebut dapat memotivasi siswa untuk semangat dalam mengikuti proses pembelajaran serta menarik perhatian siswa sehingga dapat meningkatkan hasil belajar siswa. Model pembelajaran yang berusaha meletakan dasar dan mengembangkan cara berfikir ilmiah, pendekatan ini menempatkan siswa lebih banyak belejar sendiri mengembangkan kekreatifan dalam memecahkan masalah.

Dari permasalahan tersebut, muncul identifikasi masalah sebagai berikut : (1) Proses pembelajaran yang berlangsung masih berpusat pada guru, sehingga siswa kurang aktif dalam proses pembelajaran. (2) Guru kurang menyajikan kegiatan pembelajaran yang beragam sehingga membuat siswa kurang termotivasi untuk belajar. (3) Hasil belajar siswa rendah, hal ini dikarenakan proses pembelajaran yang dilakukan oleh guru kurang inovatif.

Rumusan masalah dalam penelitian ini adalah (1) Apakah penerapan model pembelajaran Discovery Learning dapat meningkatkan hasil belajar IPA materi Ekosistem bagi siswa kelas V SD Muhammadiyah Klepu Kabupaten Sleman?. (2) Bagaimana penerapan model pembelajaran Discovery Learning pada pembelajaran IPA materi Ekosistem bagi siswa Kelas V SD Muhammadiyah Klepu Kabupaten Sleman?

Berdasarkan rumusan masalah di atas, maka tujuan dari penelitian ini adalah (1) Untuk mengetahui apakah penerapan model pembelajaran Discovery Learning dapat meningkatkan hasil belajar IPA materi Ekosistem bagi siswa kelas V SD Muhammadiyah Klepu Kabupaten Sleman. (2) Untuk mengetahui bagaimana penerapan model pembelajaran Discovery Learning pada pembelajaran IPA materi Ekosistem siswa Kelas V SD Muhammadiyah Klepu Kabupaten Sleman.

\section{METODE PENELITIAN}

Penelitian ini merupakan penelitian tindakan kelas (PTK) atau Classroom Action Research (CAR). Subjek dalam penelitian ini adalah siswa kelas V SD Muhammadiyah Klepu Sleman Tahun Pelajaran 2018/2019. Objek dalam penelitian ini adalah pembelajaran IPA dengan model Discovery Learning dan hasil belajar IPA siswa kelas V SD Muhammadiyah Klepu Kabupaten Sleman. Teknik pengumpulan data yang digunakan dalam penelitian ini adalah observasi, tes, catatan guru, dan dokumentasi. Instrumen pengumpulan data yang digunakan dalam penelitian ini adalah lembar observasi, soal tes, lembar catatan guru, dan dokumentasi. Teknik analisis data dalam penelitian ini adalah analisis deskriptif, yaitu dengan membandingkan rata - rata hasil belajar dan ketuntasan belajar siswa pada mata pelajaran IPA materi Ekosistem sebelum dan sesudah diterapkannya model pembelajaran Discovery Leraning. Penskoran dalam penelitian ini dilakukan dengan cara (1) menghitung nilai rata - rata., (2) menghitung ketuntasan belajar.

\section{HASIL DAN PEMBAHASAN}

Hasil penelitian ini menunjukkan bahwa pembelajaran melalui model pembelajaran Discovery Learning dapat meningkatkan hasil belajar IPA siswa. Nilai rata - rata post-test Siklus I adalah 62,2 . Siswa yang tuntas belajarnya berdasarkan nilai post-test siklus I hanya 2 siswa, dari 21 siswa. Bila dipersentasekan hasil post-test adalah 9,5\%, sehingga dari hasil tersebut belum bisa dikatakan bahwa hasil belajar siswa tuntas, karena yang memperoleh nilai 75 keatas belum mencapai $75 \%$. Pada siklus II nilai rata - rata post-testnya adalah 80,91 . Siswa yang tuntas belajarnya berdasarkan nilai post-test siklus II adalah 16 siswa, dari 21 siswa. Bila dipersentasekan nilai post-test siklus II adalah 76,2\%, sehingga dari hasil 
tersebut bisa dikatakan bahwa hasil belajar siswa tuntas, karena yang memperoleh nilai 75 keatas mencapai 76,2\%. Hal ini disebabkan karena dalam proses pembelajaran Discovery Learning siswa dituntut untuk bekerja sama dengan teman satu kelompok untuk mengerjakan lembar kerja IPA dari guru. Pada saat kerja kelompok setiap anggota saling kerja sama dalam memecahkan masalah. Siswa yang mampu memecahkan masalah mengajari siswa yang belum mampu memecahkan masalah dan pada akhirnya membuat semua siswa mampu memecahkan masalah. Sehingga pada saat siswa mengerjakan tes, hasilnya memuaskan. Hal tersebut sesuai dengan pendapat Sagala (2014:196) Discovery learning merupakan model pembelajaran yang berusaha meletakan dasar dan mengembangkan cara berfikir ilmiah, pendekatan ini menempatkan siswa lebih banyak belejar sendiri mengembangkan kekreatifan dalam memecahkan masalah.

\section{SIMPULAN}

Berdasarkan hasil penelitian yang dilaksanakan dalam dua siklus, maka dapat diambil kesimpulan sebagai berikut (1) Hasil penelitian yang telah dilaksanakan, menunjukkan bahwa model pembelajaran Discovery Learning dapat meningkatkan hasil belajar IPA siswa kelas V SD Muhammadiyah Klepu Kabupaten Sleman pada materi Ekosistem. Pada penelitian ini rata - rata hasil belajar IPA dan persentase ketuntasan siklus I mengalami peningkatan pada siklus II. (2) Penerapan model pembelajaran Discovery Learning akan efektif jika: (a) Guru pada saat pembentukan kelompok guru memberikan pengertian kepada siswa bahwa tujuan dibentuk kelompok adalah agar lebih mengenal temannya dikelas, supaya siswa mau untuk diatur oleh guru dalam pembentukan kelompok. Karena jika tidak, siswa akan cenderung memilih sendiri anggota kelompoknya. (b) Pada awal pembelajaran guru membuat suasana kelas menjadi menyenangkan, salahsatunya dengan mengajak siswa untuk menyanyikan lagu bersama - sama, tujuannya agar suasana kelas menjadi menyenangkan dan diharapkan siswa menjadi lebih siap untuk belajar.

Berdasarkan hasil dari penelitian ini, ada beberapa saran yang perlu dipertimbangkan dalam menggunakan model pembelajaran Discovery Learning untuk mata pelajaran IPA adalah sebagai berikut (1) Siswa diharapkan menanyakan kepada teman atau guru mengenai materi pelajaran yang dianggap belum jelas. (2) Guru diharapkan mempelajari model pembelajaran Discovery Learning agar mampu menerapkannya dalam proses pembelajaran. (3) Pembelajaran IPA melalui model pembelajaran Discovery Learning agar dapat digunakan sebagai alternatif model pembelajaran IPA di Kelas V SD Muhammadiyah Klepu tahun pelajaran 2018/2019.

\section{DAFTAR PUSTAKA}

Arikunto, Suharsimi, dkk. 2012. Penelitian Tindakan Kelas. Jakarta: Bumi Aksara.

Kunandar. 2011. Langkah Mudah Penelitian Tindakan Kelas. Jakarta: Rajawali Pers. S, Sagala. 2014. Konsep dan Makna Pembelajaran. Bandung: Alfabeta.

Wisudawati, Asih Widi, dan Sulistyowati, Eka. 2014. Metodologi Pembelajaran IPA. Jakarta: Bumi Aksara. 